\title{
Robustness of and challenges to public health colleges: the case of Somalia
}

Abdulkadir Muse ${ }^{1}$ and Abdiwahab Hassan²

${ }^{1}$ Program Coordinator, Somali Institute for Development Research and Analysis (SIDRA) Garowe, Puntland, Somalia. ${ }^{2}$ Somali Institute for Development Research and Analysis (SIDRA), Rochester, Minnesota, United States of America (Correspondence to: Abdulkadir Muse: abdulkadir.mm@sidrainstitute. org).

Citation: Muse A; Hassan A. Robustness of and challenges to public health colleges: the case of Somalia. East Mediterr Health J. 2021;27(7):646-647. https://doi.org/10.26719/2021.27.7.646

Received: 20/07/20; accepted: 04/04/21

Copyright @ World Health Organization (WHO) 2021. Open Access. Some rights reserved. This work is available under the CC BY-NC-SA 3.0 IGO license (https://creativecommons.org/licenses/by-nc-sa/3.o/igo).

\section{Somalia: public health in context}

War is a public health issue (1). Somalia's health infrastructure has been completely destroyed by the civil war that broke out in 1990 (2). As a result, and as expected in war zones, Somalia's health status has drastically declined. Droughts, famines, outbreaks (of disease or fighting, for example) and economic decline have exacerbated the situation (3).

In armed conflicts, health services focus on treating the injured and the sick. Preventive and health promotion activities are greatly reduced (4). Lack of basic life needs (e.g. water, food and shelter) is the main concern of the people in war. Immunization, clean water, personal hygiene and maternal health, although essential for disease prevention, are the least of their concerns. Therefore, the result of the civil war in Somalia was an inevitable increase in mortality and morbidity across the country.

The international community, collaborating with local people, has always supported Somalia in its search for peace and health promotion.

In recent years, the Somali people have shown a great interest in establishing universities in Somalia offering opportunities for ambitious students. Surprisingly, Somalia has more universities than its neighbouring countries Kenya and Ethiopia, which have 58 and 36 universities, respectively; Mogadishu, the capital of Somalia, alone, is reported to have about 40 universities (5).

In a 2013 survey of 44 universities in Somalia, 7005 students were enrolled in the faculty of public health and health studies (6). Students enrolling in public health colleges are increasing although a regional variation is observed (6). This awakening shows that people in Somalia recognize the need for early prevention strategies rather than reaction after an outbreak. This is a Somali, postconflict public health era. An era of prevention rather than hospitalization.

\section{Building a generation: public health colleges}

Proper university education and rigorous training of the students pursuing public health can bring a rapid, positive change in Somalia's health status. Although universities offering a degree in public health exist in Somalia, the quality of such courses may be questioned (6). Individuals, organizations and local authorities that have played a role in establishing those colleges in Somalia should be applauded for their efforts.

These public health colleges bring the opportunity to empower students to lead and conduct scientific studies that can contribute to better health in Somalia. Furthermore, with their passion and enthusiasm, the graduates, if properly supported, will soon envision successful disease prevention, elimination and eradication strategies suitable for Somalia's long-lasting health problems.

Limited funding, shortage of qualified staff and lack of or limited research publications are major challenges faced by universities in Somalia. Despite the challenges and civil unrest a country or region suffers, investing in and educating the new generations always revives hope and peace. Therefore, national, and particularly international, support is important in Somalia's public health education endeavour.

\section{Barriers to academic research development}

Currently, little research is conducted by higher education institutions in Somalia $(5,6)$ due to a number of barriers as listed below $(3,5)$.

Limited or lack of qualified staff. The shortage or sometimes the absence of experienced researchers in educational institutions is a constraint in the production of health research in Somalia. Factors such as knowledge of English, internet access and access to the literature are major barriers for Somali researchers (5).

Limited funding. Universities receive limited funding from the government $(5,6)$. It is reported that "the education sector receives $4.6 \%$ of the [federal] budget" 
and that the "majority" of that budget "goes to primary education" (5).

Poor national and regional research agenda. With the right national agenda, research can accelerate Somalia's development and help the country's health recovery. However, the federal and regional governments are not involved in academic research therefore researchers receive no incentives (5).

Lack of support and collaboration. Some international research collaboration has been initiated in Somalia. However, quality standards of the Somali universities and insecurity are major barriers (5).

\section{The international community: forgotten roles and responsibilities}

When international humanitarian operations are mentioned in Somalia, drought, famine and other health emergencies come to mind. Although the importance of those operations in such life-threatening situations cannot be underestimated, the fact is that Somalia doesn't just need food, medical supplies and global health volunteers, it also requires intellectual support.

International support for Somalia's public health colleges could include the following undertakings.

- Health research development through funding research projects of the universities and local research organizations. Moreover, international research or- ganizations and universities (wherever they are) should reach out to public health colleges in Somalia for collaboration.

- Virtual communications with opportunities for events such as training, seminars, symposiums, and conferences to give students an invaluable opportunity to learn from the experiences in other parts of the world.

- Academic exchange with opportunities for research fellowships and postgraduate studies for Somali researchers.

All forms of international support are vital for the improvement of public health education in Somalia.

\section{The future: what lies ahead?}

Establishing public health colleges in Somalia is a sign of a brighter future for the Somali people who have suffered major health emergencies.

National public health strategies will be more effective when sufficient data are generated by extensive scientific research in every city, town and village in Somalia conducted by well-trained local researchers.

Public health students in Somalia are the future of the country's public health workforce that will flatten the curve of many health issues, and Somalia urgently needs that.

\section{References}

1. Murray CJL, King G, Lopez AD, Tomijima N, Krug EG. Armed conflict as a public health problem. BMJ. 2002;324(7333):346-9. https://doi.org/10.1136/bmj.324.7333.346

2. Warsame A, Handuleh J, Patel P. Prioritization in Somali health system strengthening: a qualitative study. Int Health. 2016;8(3):204-10. https://doi.org/10.1093/inthealth/ihvo6o

3. Dalmar AA, Hussein AS, Walhad SA, Ibrahim AO, Abdi AA, Ali MK, et al. Rebuilding research capacity in fragile states: the case of a Somali-Swedish global health initiative. Glob Health Action. 2017;10(1):1348693. https://doi.org/10.1080/16549716.2017.1348693

4. Sato R. Effect of armed conflict on vaccination: evidence from the Boko haram insurgency in northeastern Nigeria. Confl Health. 2019;13:49. https://doi.org/10.1186/s13031-019-0235-8

5. Pellini A, Abdi DI, Salah G, Ali HY, Quintin KL, Hassan MA, et al. Research in Somalia: opportunities for cooperation. London: Overseas Development Institute (ODI); 2020 (https://www.econstor.eu/handle/10419/216987, accessed 10 July 2020).

6. The State of higher education in Somalia: privatization, rapid growth, and the need for regulation. Mogadishu: The Heritage Institute for Policy Studies; 2013 (https://www.heritageinstitute.org/wp-content/uploads/2013/08/HIPS_Higher_Education_ENGLISH.pdf, accessed 10 July 2020). 